\title{
Production and Purification of Laccase Enzyme by Klebsiella pneumoniae $\mathrm{K} 7$
}

\author{
Doaa Khalid Mezaal ${ }^{1} \quad$ Essam Fadel Al-Jumaili ${ }^{* 1} \quad$ Ahmed Majeed Al-Shammari ${ }^{2}$ \\ 1.Biotechnology Dept. Genetic Engineering and Biotechnology Institute for Post Graduate Studies / University \\ of Baghdad/ Iraq \\ 2.Experimental Therapy Dept. Iraqi Centre for Cancer Medical Genetic Research, Mastansiriyeh University
}

\begin{abstract}
Sixty-four isolate were klebsiella pneumoniae. Fourteen bacteria isolates "Kelbsiella species" were taken from soil and water hospital in the period between October to December 2018, those isolated were cultured on a blood agar to test their ability to hydrolytic due to formation the inhibition zone. Twenty one isolates of $K$. pneumoniae were selected to be cultured in mineral salt agar for testing their efficiency to produce laccase enzyme .The efficient isolate was diagnosed depending on phenotypic, microscopic and biochemical tests to be Klebsiella pneumoniae K7. Laccases (benzenediol: oxygen oxidoreductases; EC: 1.10.3.2) are subfamily of multicopper oxidases (MCOs) from Klebsiella pneumoniae K7 has been partially characterized by many researchers. In this paper, we purified laccase to homogeneity from Klebsiella pneumoniae K7 with about $10.82 ; 5.12$ purification fold and a 34.14; $21.46 \%$ recovery by ion-exchange and gel-filtration chromatographic respectively. The molecular weight of the Laccase as determined by gel filtration chromatography using Sephacryl S-200 gel was 120 KDalton.
\end{abstract}

Keywords: Laccases, Klebsiella pneumoniae, molecular weight, purification.

DOI: $10.7176 / \mathrm{CMR} / 10-5-03$

Publication date:May $31^{\text {st }} 2020$

\section{INTRODUCTION}

Laccases (benzenediol: oxygen oxidoreductases ; EC: 1.10.3.2) are subfamily of multicopper oxidases (MCOs), which catalyze the one electron oxidation of four reducing-substrate molecules concomitant with the four-electron reduction of molecular oxygen to water. Laccase was first described from the sap of the Japanese lacquer tree Rhus vernicifera. Also laccases are wide spread in fungi, bacteria and insects (Rezaei et al., 2017)[1]. Laccases have a good potential for industrial and environmental applications (Viswanath et al., 2014)[2].

The utilization of bacterial laccases are growing rapidly and became outstanding biocatalysts that applied in different fields. This is because they have many features included: the bacterial systems are easier to handle than fungal ones, work in a broad range of temperature and $\mathrm{pH}$ with enormous stability against various inhibitory agents (Guan et al. , 2018)[3].Liu et al. , (2017)[4] purified thermostable and $\mathrm{pH}$-stable laccase from K.pneumoniae which isolated from soil, the laccase cloned and expressed in E. coli., rLac purified with the 6-His tag, the cells were harvested by centrifugation, the supernatant was collected by centrifugation and applied to a nickelnitrilotriacetic acid (Ni-NTA) agarose gel column. The purity and apparent molecular mass of the rLac were monitored by sodium dodecyl sulfate polyacrylamide gel electrophoresis (SDS-PAGE). Laccases are exist in a different forms: monomeric, dimeric and tetrameric glycoprotein with molecular mass ranges from 50 to $140 \mathrm{kDa}$, depending on the organism (Jaiswal et al. , 2015)[5], The molecular weight of bacterial laccases are within the range 60 to $112 \mathrm{kDa}$ (monomer was 32 to $44 \mathrm{kDa}$ ). The bacterial laccases were found to be thermostable and alkaline stable (Sharma et al., 2007)[6]. Baldrian (2006)[7] suggested that the location of laccase depends on the substrate and its physiological function. Therefore, the aim of the study were to isolate and identify a local laccase producing strain of Klebsiella pneumoniae, and to purify and characterize the laccase produced by the bacterium.

\section{MATERIALS AND METHODS}

Isolation and identification of bacteria

The Samples of soil and water were collected from different sites in Baghdad city: Tigris, Al Rustamiya Sewage Station, Dora Refinery, Gas station, Electricity generators, Gardens and Water pools at Baghdad University and Car repair places. The isolation of bacteria was based on serial dilution method technique. In this, one gram soil or $1 \mathrm{ml}$ of water was added to a tube containing $9 \mathrm{ml}$ of PBS solution and mixed vigorously for 30s. The suspension was serially diluted from $10^{-1}$ to $10^{-8}$ dilution factors and $0.1 \mathrm{ml}$ of each dilution was spread on the surface of MacConkey medium by spread plate method, then the plates were incubated at $37^{\circ} \mathrm{C}$ for $(24-48) \mathrm{hrs}$ and then examined for bacterial growth. After the growth the bacteria isolates, they subculture by streaking on MacConkey agar, incubated at $37^{\circ} \mathrm{C}$ for $24 \mathrm{hrs}$ and take colony for identifying it.

\section{Screening of laccase producing bacteria}

The screening of bacteria that have ability to produce laccase were done by using:

Trace Element Solution -1 : 0.10g ZnSO $\mathrm{Zn}_{4} .7 \mathrm{H}_{2} \mathrm{O}, 0.03 \mathrm{~g} \mathrm{MnCl} 2.4 \mathrm{H}_{2} \mathrm{O}, 0.30 \mathrm{~g} \mathrm{H}_{3} \mathrm{BO}_{3}, 0.20 \mathrm{~g} \mathrm{CoCl}_{2} .6 \mathrm{H}_{2} \mathrm{O}, 0.01 \mathrm{~g}$ 
$\mathrm{CuCl}_{2} .2 \mathrm{H}_{2} \mathrm{O}, 0.02 \mathrm{~g} \mathrm{NiCl}_{2} .6 \mathrm{H}_{2} \mathrm{O}, 0.03 \mathrm{~g} \mathrm{Na}_{2} \mathrm{MnO}_{4} \cdot 2 \mathrm{H}_{2} \mathrm{O}$ dissolved in $1000 \mathrm{ml}$ Distilled water.

Trace Element Solution -2: $0.10 \mathrm{~g}$ EDTA, 0.03g FeSO $4.7 \mathrm{H}_{2} \mathrm{O}, 100 \mathrm{ml}$ Trace Element Solution-1 dissolved in $1000 \mathrm{ml}$ Distilled water.

Mineral salt media $3.5 \mathrm{~g} \quad \mathrm{Na}_{2} \mathrm{HPO} 4.2 \mathrm{H}_{2} \mathrm{O}, 1.0 \mathrm{~g} \quad \mathrm{KH}_{2} \mathrm{PO}_{4}, 0.5 \mathrm{~g}\left(\mathrm{NH}_{4}\right)_{2} \mathrm{SO}_{4}, 0.1 \mathrm{~g} \quad \mathrm{MgCl}_{2} .6 \mathrm{H}_{2} \mathrm{O}, 0.05 \mathrm{~g}$ $\mathrm{Ca}\left(\mathrm{NO}_{3}\right)_{2} \cdot 4 \mathrm{H}_{2} \mathrm{O}$ and $1 \mathrm{ml}$ Trace Element Solution-2

These components were dissolved in $900 \mathrm{ml}$ of distilled water (D.W), $\mathrm{pH}$ was adjusted to ( $7 \pm 0.2)$, and the volume completed to $1000 \mathrm{ml}$. The media then sterilized by autoclave at $121^{\circ} \mathrm{C}$ and $15 \mathrm{psi}$ for $15 \mathrm{~min}$.

\section{Methyl orange plate screen assay}

This prepared in by adding $0.1 \mathrm{~g} / 1$ of Methyl Orange (after filtering it) in sterilized Mineral Salt Agar. Drop $5 \mu \mathrm{L}$ of overnight culture onto the plate (when this dries it will form a little circle), incubated at $37^{\circ} \mathrm{C}$ for $24 \mathrm{hrs}$. A clear zone of methyl orange hydrolysis around the drop was an indication of laccase secretion.

\section{ABTS plate screen assay}

The isolates showing methyl orange degradation were further screened for enzyme laccase, on this media which prepared by adding $0.2 \mathrm{mM}$ ABTS and $0.1 \mathrm{mM} \mathrm{CuSO}_{4}$ (after filtering them) in Mineral Salt Agar. Blue green oxidation zone around the bacteria colony indicated the presence of laccase.

\section{Laccase assay}

Laccase activity was monitored by measuring the maximum absorption of oxidation of $\mathrm{ABTS}$ at $25^{\circ} \mathrm{C}$ as a substrate. The reaction mixture containing $1 \mathrm{ml}$ of crude enzyme and $1 \mathrm{ml}$ of ABTS $(0.2 \mathrm{mM})$. The oxidation of ABTS was determined by measuring the absorbance at $420 \mathrm{~nm}$ using a spectrophotometer. The blank mixture containing $1 \mathrm{ml}$ of sodium acetate buffer $(0.1 \mathrm{mM}, \mathrm{pH} 5)$ and $1 \mathrm{ml}$ of ABTS . Laccase activity was calculated as follows:

$$
\text { Laccase activity }\left(\frac{\mathrm{U}}{\mathrm{ml}}\right)=\frac{\mathrm{A} \times \mathrm{V} \times 106}{€ \mathrm{ABTS} \times \mathrm{t} \times \mathrm{v}}
$$

Where: A: Absorbance at $420 \mathrm{~nm}$; V: Total volume of reaction mixture in $(\mathrm{ml}) ; €$ : molar extinction coefficient of $\mathrm{ABTS}=36000 \mathrm{M}^{-1} \mathrm{~cm}^{-1}$; t:incubation time $(1 \mathrm{~min})$ and $\mathrm{v}$ : volume of enzyme used in $(\mathrm{ml})$

One unit of enzyme activity was defined as the amount of enzyme catalyzing the oxidation of $1 \mu \mathrm{mol}$ of substrate per minute. Protein concentration was assayed by the method of Bradford (1976)[8] and Stoscheck (1990)[9], with bovine serum albumin as standard.

\section{Crude enzyme}

The isolate, that have the highest enzyme activity, was incubated into fifty hundred milliliter of Luria bertani broth in sterile Erlenmeyer flasks at $37^{\circ} \mathrm{C}$ for $24 \mathrm{hrs}$ on a shaker incubator with $120 \mathrm{rpm}$. After $24 \mathrm{hrs}$, the broth culture was filtrate by using cooling centrifuge at $15000 \mathrm{rpm}$ and $4^{\circ} \mathrm{C}$ for $5 \mathrm{~min}$ to obtain supernatant, this supernatant used as crude laccase, which stored at $4^{\circ} \mathrm{C}$ for further purification steps. The laccase activity in the supernatant was determined spectrophotometrically with the ABTS assay.

\section{Ammonium Sulfate Precipitation}

The ammonium sulfate was added in different saturation ratios (0-100\%) into crude enzyme. To reach the optimum ratio of ammonium sulfate, the amount of salt was add gradually to crude enzyme solution in ice bath with gently magnetic stirrer, to avoid foaming, for $1 \mathrm{hr}$. The resulting solution was kept stationary overnight and centrifuged at $10000 \mathrm{rpm}$ for $20 \mathrm{~min}$, dropped the supernatant and take the precipitate, dissolved it in $5 \mathrm{ml}$ Tric- $\mathrm{HCl}$ buffer $(0.05 \mathrm{M}, \mathrm{pH}=8.0)$, and calculated the activity and protein concentration. The supernatant was then subjected to ammonium sulfate precipitation. The precipitate obtained was dialyzed and then loaded onto a DEAE-Cellulose anion-exchange column.

\section{Ion exchange chromatography}

The exchanger DEAE-cellulose was prepared and packed into column following the method described by Whitaker, (1972)[10]. A column with a diameter of $(7.5 \times 2.5 \mathrm{~cm})$ was equilibration with $0.05 \mathrm{mM} \mathrm{Tris- \textrm {HCl }}$ buffer $\mathrm{pH}$ 8.0. Partially purified concentrated laccase enzyme $(12 \mathrm{ml})$ were separately passed after loaded onto the column carefully. Then $(100 \mathrm{ml})$ of $(0.05 \mathrm{mM})$ Tris- $\mathrm{HCl}$ buffer $\mathrm{pH}(8.0)$ was added. Proteins were eluted by using $(200 \mathrm{ml})$ of a stepwise salt concentration from $(0.125-1.0 \mathrm{M})$ in $0.05 \mathrm{mM}$ Tris-HCl buffer $(\mathrm{pH} 8.0)$. Fractions of $(5$ $\mathrm{ml})$ were collected and absorbency was monitored at $(280 \mathrm{~nm})$. The presence of the Laccase enzyme were estimated from each fraction of the major peaks then protein concentration and specific activities were determined for the collected active fractions.

\section{Gel filtration chromatography}

Sephacryl S-200 column $(60 \times 1.5 \mathrm{~cm})$ was prepared and packed according to the instruction of the manufacturing 
company. The column was equilibrated with $(0.05 \mathrm{mM})$ Tris- $\mathrm{HCl}$ buffer ( $\mathrm{pH}-8.0)$ at a flow rate of $(50 \mathrm{ml} / \mathrm{hour})$. A $(5 \mathrm{ml})$ sample of each concentrated partially purified laccase enzyme was added to the column, carefully using pasture pipette. A $(5 \mathrm{ml})$ fraction were collected for each laccase then protein contents were estimated by measuring the absorbance at $(280 \mathrm{~nm})$. Laccase activity was determined for each fraction of the major peaks. Protein concentrations and specific activities were also determined for the collected fractions of the major peaks of the Laccase enzyme.

\section{Determination of the molecular weight}

Molecular weight was determined by gel filtration chromatography by using Sepharose 6B, (Laue and Rhodes, 1990)[11] and the standard proteins used for the standard curve and their relevant molecular weights were (Catalase, 230000; Arginine deaminase , 125000; Alkaline phosphatase, 80000; Bovine serum albumin, 67000; Pepsin 34000).

\section{RESULTS AND DISCUSSION}

Isolation and Identification of the Bacteria :

Fifty eight samples that collected of soil and water samples were used for isolated klebsiella. , several morphological, physiological and biochemical tests were made to identify the isolates. The results of bacterial subculture on MacConkey and biochemical test showed that 64 isolate were $k$. pneumoniae. (Table 1).

Table (1): Biochemical test of klebsiella.

\begin{tabular}{|l|c|}
\hline \multicolumn{1}{|c||}{ Biochemical test } & Klebsiella \\
\hline \hline Catalase & + \\
\hline \hline Oxidase & - \\
\hline Indole production & - \\
\hline \hline Voges proskauer & + \\
\hline \hline Methyl red & - \\
\hline \hline Simmon's citrate & + \\
\hline \hline Urease & + \\
\hline
\end{tabular}

Screening of Klebsiella pneumoniae Isolates for Laccase Production :

Out of sixty four Klebsiella pneumoniae isolates, there were thirty isolates showed a clear zone around the colony on methyl orange plate, these isolate further screened for enzyme laccase on ABTs plate, it found that twenty one give a positive results. The activity of the enzyme of the twenty one isolates of $K$. pneumoniae, that have ability to produce laccase, was measured to select the highest isolation activity for choose the isolate that have the highest activity (Table 2). The laccase enzyme extraction then the laccase activity was monitored by measuring the maximum absorption of oxidation of ABTS as a substrate.

Table (2) : Screening the Klebsiella pneumoniae producing Laccase enzyme.

\begin{tabular}{|c||c|}
\hline Klebsiella pneumoniae Isolates & Enzyme activity (Unit/ml) \\
\hline K1 & 4.69 \\
\hline K2 & 6.11 \\
\hline K3 & 5.54 \\
\hline K4 & 8.23 \\
\hline K5 & 7.60 \\
\hline K6 & 6.57 \\
\hline K7 & 12 \\
\hline K8 & 6.78 \\
\hline K9 & 7.83 \\
\hline K10 & 9.54 \\
\hline K11 & 6.97 \\
\hline K12 & 7.94 \\
\hline K13 & 10.23 \\
\hline K14 & 6.50 \\
\hline K15 & 7.21 \\
\hline K16 & 9.37 \\
\hline K17 & 7.08 \\
\hline K18 & 10.06 \\
\hline & \\
\hline & \\
\hline & \\
\hline & \\
\hline
\end{tabular}




\begin{tabular}{|c|c|}
\hline Klebsiella pneumoniae Isolates & Enzyme activity (Unit/ml) \\
\hline \hline K19 & 8.46 \\
\hline K20 & 5.26 \\
\hline K21 & 5.94 \\
\hline
\end{tabular}

\section{Crude Extraction:}

The laccase enzyme was extracted from the local isolation of $K$. pneumonia after incubated in Luria broth in the shaker incubator at $37^{\circ} \mathrm{C}$ for $24 \mathrm{hrs}$. The production medium contains the laccase enzyme that was excreted outside the cell bacterial to the medium of culture production. After centrifuge, the volume of crude enzyme was $300 \mathrm{ml}$ with enzyme activity $146 \mathrm{U} / \mathrm{ml}$ and specific enzyme $0.695 \mathrm{U} / \mathrm{mg}$ protein, as shown in Table (3).

\section{Ammonium Sulfate Precipitation:}

The crude enzyme extract was fractionated with different percentage of ammonium sulphate $(0-100 \%)$. The results of specific activity of supernatant were showed in Table (3), the higher specific activity was $(1.21 \mathrm{U} / \mathrm{mg})$ at $(60-80 \%)$ than other saturation of ammonium sulphate.

Table (3) : Fractionated Laccase produce from $K$. pneumonia $K 7$ with different percentage of ammonium sulphate.

\begin{tabular}{|c||c|}
\hline Ammonium sulfate (\%) & Specific activity (Unit/mg protein) \\
\hline $0-20$ & 0.12 \\
\hline $20-40$ & 0.78 \\
\hline $40-60$ & 1.12 \\
\hline $60-80$ & 1.21 \\
\hline \hline $80-100$ & 1.16 \\
\hline
\end{tabular}

Ionic Exchange Chromatography :

Laccase enzyme was obtained by using buffer solution at concentration of $20 \mathrm{mM}$ Tris -base $\mathrm{pH} 8.3$. Absorbance of eluted fractions were measured at $280 \mathrm{~nm}$ upon the arrival of absorbance to the line of zero (line base), then same buffer with stepwise of $\mathrm{NaCl}(0.125-1 \mathrm{M})$ used to elute the bounded protein. Ionic exchange chromatography patterns showed two protein peak in wash elution and two peaks in stepwise elution. Only one peak among the stepwise elution peaks represented enzyme activity (tubes 28-39). Those fractions pooled and tested for specific activity ( $3.65 \mathrm{U} / \mathrm{mg}$ ) a fold purification of (5.12) and enzyme yield of (34.14\%) in parts. (Figure 1).

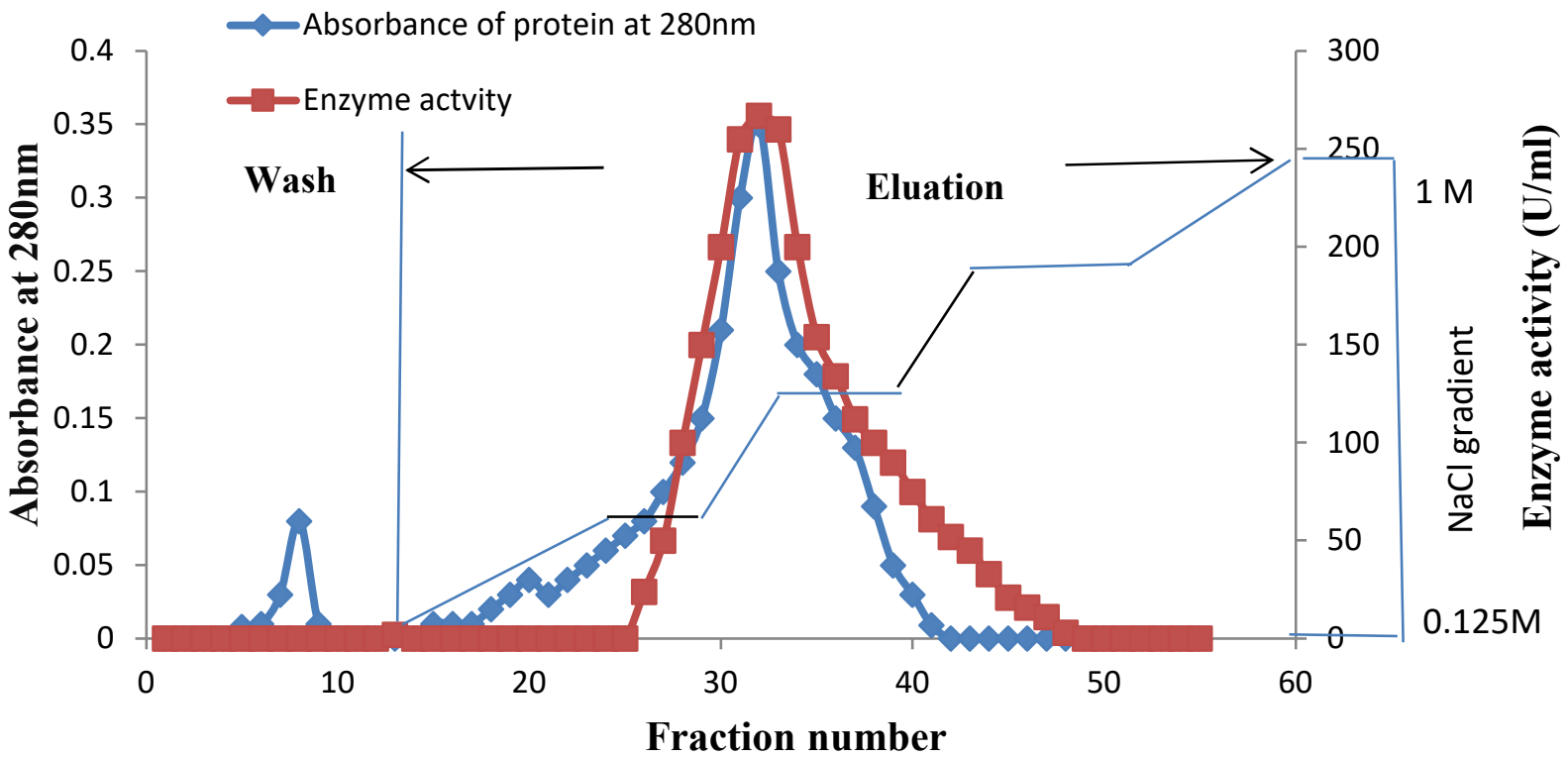

Figure (1): Ionic exchange chromatography for Laccase enyme from K. puomonae K4 through DEAE-cellulose column $(2.5 \times 7.5 \mathrm{~cm})$. The column was calibrated with $0.05 \mathrm{mM}$ Tris-HCl buffer $\mathrm{pH} 8.0$ flow rate $60 \mathrm{ml} / \mathrm{hrs}$ and $5 \mathrm{ml}$ fraction, eluted with stepwise ( 0.125-1 M) $\mathrm{NaCl}$. 
Gel filtration Chromatography:

Purification carried out by a gel filtration using Sephacryl S-200. Enzymes fraction from DEAE cellulose were pooled and passed through gel filtration column. The fractionation yielded two protein peaks as absorbance reading at $280 \mathrm{~nm}$ (wave length), only one peak where appeared when reading absorbance at wavelength of 280 $\mathrm{nm}$ and when determined for enzyme activity in resulting parts enzyme activity recorded in 16-20, the specific activity reached $7.52 \mathrm{U} / \mathrm{mg}$, fold of 10.82 and a yield $21.46 \%$ as mentioned in table (3) and figure (2). Laccase from $T$. versicolour is purified with Ion Exchange chromatography followed by gel filtration with specific activity of $101 \mathrm{UmL}-1$ and 34.8 fold purification. (Cordi et al,,2007)[12].

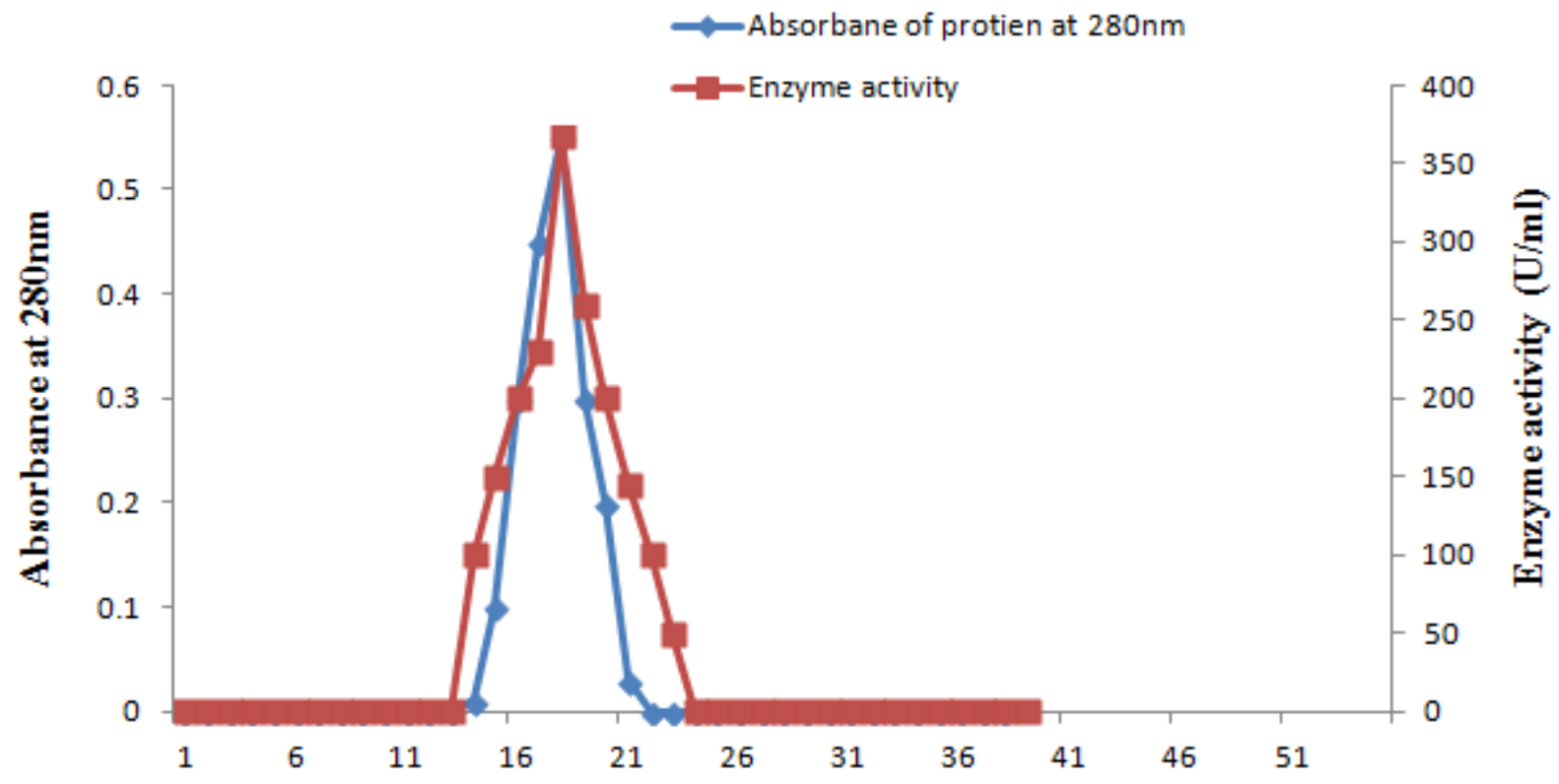

Fraction number

Figure (2): Gel filtration chromatography for purification Laccase from Klebsiella pneumoniae K4. using Sephacryl S-200 column $(60 \times 2.0 \mathrm{~cm}) \mathrm{cm}$. The column was calibrated with $0.05 \mathrm{mM}$ Tris-HCl buffer $\mathrm{pH} 8.0$; flow rate $50 \mathrm{ml} / \mathrm{hrs}$ and 5 ml/fraction.

Table(3):Purification steps of Laccase produced from Klebsiella pneumoniae K4.

\begin{tabular}{|c|c|c|c|c|c|c|c||}
\hline $\begin{array}{c}\text { Purification } \\
\text { step }\end{array}$ & $\begin{array}{c}\text { Volume } \\
(\mathbf{m l})\end{array}$ & $\begin{array}{c}\text { Enzyme } \\
\text { activity } \\
\mathbf{( U / m )}\end{array}$ & $\begin{array}{c}\text { Protein } \\
\text { concentration } \\
(\mathbf{m g} / \mathbf{m l})\end{array}$ & $\begin{array}{c}\text { Specific } \\
\text { activity } \\
\text { (U/mg) }\end{array}$ & $\begin{array}{c}\text { Total } \\
\text { activity } \\
\text { (U) }\end{array}$ & $\begin{array}{l}\text { Purification } \\
\text { fold }\end{array}$ & $\begin{array}{l}\text { Yield } \\
(\%)\end{array}$ \\
\hline Crude enzyme & 300 & 146 & 210 & 0.695 & 43800 & 1 & 100 \\
\hline $\begin{array}{c}\text { Ammonium } \\
\text { Sulfate } \\
\text { Precipitation }\end{array}$ & 132 & 213 & 176 & 1.210 & 28116 & 1.74 & 64.19 \\
\hline Ion exchange & 56 & 267 & 75 & 3.56 & 14952 & 5.12 & 34.14 \\
\hline Gel filtration & 25 & 376 & 50 & 7.52 & 9400 & 10.82 & 21.46 \\
\hline
\end{tabular}

The molecular weight was estimated by gel filtration depending on the size of the separated molecules with their charge .It was possible that the different methods of estimation may be used.(Segal,1992)[13]. Sephacryl S200 for gel filtration was used for estimation the molecular weight of Laccase enzyme that purified from Klebsiella pneumoniae K4 illustrated in figure (3). The logarithm molecular weight standard protein versus elution volume / void volume ratio (Ve/ V0) was the basis to estimate the molecular weight. By using this relationship, the molecular weight of the enzyme was estimated with 120000 Dalton.

This result, compared with Singh et al. (2008)[14] determined the molecular weight of laccase that purified from c-Proteobacterium JB By using ABTS as substrate .Also, Siroosi et al. (2016)[15] estimated molecular weight of laccase from Bacillus sp. WT to be 180KD and Verma and Shirkot (2014)[16] purified laccase from Geobacillus thermocatenulatus MS5 with molecular weight 42.5KD. 


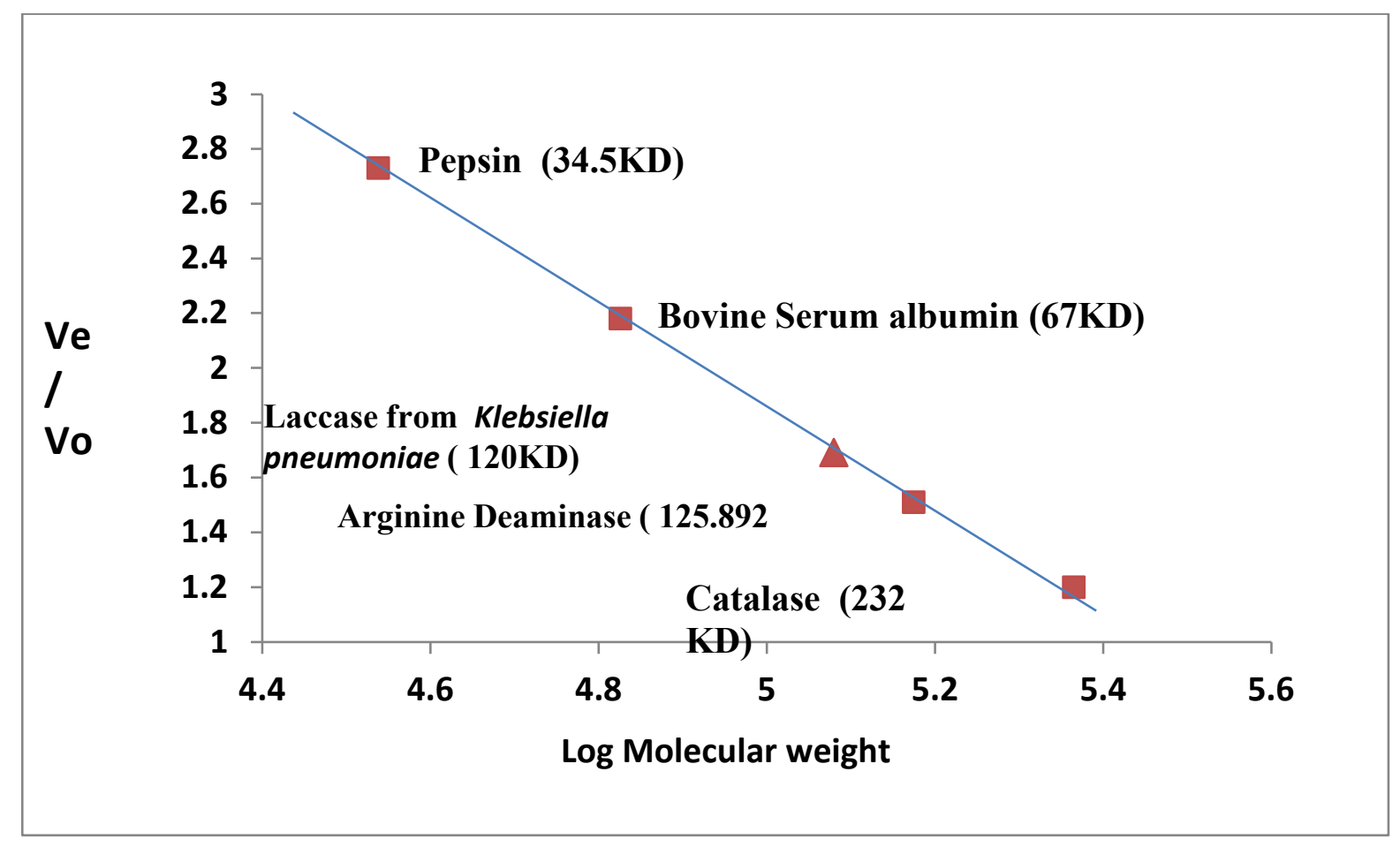

Figure (3): Standard curve to estimate molecular weight of Laccase enzyme produced by Klebsiella pneumoniae K4 using gel filtration by using Sephacryl S-200.

\section{Conflict of Interest}

The author knows of no financial interest or any conflict of interest relative to this article.

\section{REFERENCES}

1. Rezaei S, Shahverdi AR, Faramarzi MA (2017) Isolation, one-step affinity purification, and characterization of a polyextremotolerant laccase from the halophilic bacterium Aquisalibacillus elongatus and its application in the delignification of sugar beet pulp. Bioresour Technol 230:67-75.

2. Viswanath, B., Rajesh, B., Janardhan, A., Kumar, A.P., and Narasimha, G. (2014) Fungal laccases and their applications in bioremediation. Enzyme Res 2014: 163242.

3. Guan ZB, Liao Q, Wang HR, Chen Y, Liao XR. (2018). Bacterial laccases: promis- ing biological green tools for industrial applications. Cell Mol Life Sci.;75:3569-92.

4. Liu Q, Luo L, Wang X, Shen Z, Zheng L(2017). Comprehensive analysis of rice laccase gene (OsLAC) family and ectopic expression of OsLAC10 enhances tolerance to copper stress in Arabidopsis. Int J Mol Sci.;18:209.

5. Jaiswal N, Pandey VP, Dwivedi UN (2015) Purification of a thermostable alkaline laccase from papaya (Carica papaya) using affinity chromatography. Int J Biol Macromol 72:326-332.

6. Sharma, P., Goel, R. and Capalsh, N. (2007) Bacterial laccase, World J. Microbiol. Biotechnol., 23, 823-832.

7. Baldrian, P. (2006) Fungal laccases - occurrence and properties, FEMS Microbiol. Rev., 30, $215-242$.

8. Bradford, M. M. A rapid and sensitive method for the quantitation of microorganism's protein utilizing the principleof protein-dye binding. Analytical Bioch.72: 248-254.(1976).

9. Stoscheck, C. M. (1990) Quantitation of protein. Methods in Enzymology. 182: 50-69.

10. Whitaker, J. R. (1972). Principles of Enzymology for the Food Science. (ed. Oen, R. F. ) Marcel Dekker INC. ; New York.

11. Laue, T.M.and Rodes, D.G. Gel filtration. In: Methods in Ezynmology (ed. Deutscher, M.P.). 182:556587.Academic Press, Inc.(1990).

12. Cordi, L., R.C. Minussi, R.S. Freire and N. Duran, 2007. Fungal laccase: Copper induction, semi-purification, immobilization, phenolic effluent treatment and electrochemical measurement. Afr. J. Biotechnol., 6: 12551259.

13. Segel, I.H.(1992).Biochemical calculations ,John Wiely and sons.NewYork.2nd edition.pp344.

14. Singh G, Ahuja N, Batish M, Capalash N, Sharma P (2008). Biobleaching of wheat straw rich soda pulp with alkalo-philic laccase from c-proteobacterium JB: optimization ofprocess parameters using response surface methodology.Bioresour Technol 99:7472-7479.

15. Siroosi M, Amoozegar MA, Khajeh K.(2016). Purification and characterization of an alkaline chloride- 
tolerant laccase from a halotolerant bacterium, Bacillus sp. strain WT. J Mol Catal B Enzym. 134:89-97. doi: 10.1016/j.molcatb.2016.10.001.

16. Verma A, Shirkot P.(2014). Purification and characterization of thermostable laccase from thermophilic Geobacillus thermocatenulatus MS5 and its applications in removal of textile dyes Sch Acad. J Biosci. ;2:479-485. 